\title{
On the Definitions of Administrative Law ${ }^{1}$
}

Defining legal institutions is conventional and relative. It is relative in a double sense. First, an author may, to be sure, describe and classify existing legal matter according to arbitrarily chosen criteria, but the definitions arrived at in this manner will closely depend on the criteria, and the scope of their validity will thus be relative. Second, the very choice of criteria, and consequently the scope of obtained definitions, will be limited by the requirement that they be useable for analysing and explaining objectively existing matter. To achieve this purpose, the matter must be adequately approached, the institutions that are specified must be "clear-cut", relationships and differences must be better explained, characteristics joining or dividing legal institutions into certain groups must be exposed, etc.

For this reason, the definitions of legal institutions are as a rule of the regulating type. Their usability depends on the degree to which they can explain an existing legal contrivance. In this context, purely stipulative definitions have, as a rule, a merely speculative value.

Furthermore, an attempt to define a certain group or kind of legal contrivances may actually resemble an operation of drawing distinc-

1 Translated from: M. Zimmermann, Z zagadnień definicji prawa administracyjnego, “Acta Universitatis Wratislaviensis" 1964, 19 by Tomasz Żebrowski and proofread by Stephen Dersley and Ryszard Reisner. The translation and proofreading were financed by the Ministry of Science and Higher Education under 848/2/P-DUN/2018. A paper delivered at the Symposium of Administrative Law Chairs held in Wrocław on 12 December 1956. 
tions and making a classification, thus, requiring at least two definitions. Its purpose may be to indicate, for instance, the distinctive features of some sphere of governance. In such cases, as any classification, this, too, must use uniform criteria, lying on the same plane, i.e. a uniform dividing principle. This is to ensure an exhaustive and disjunctive division. Interestingly, the adoption of such a principle cannot be entirely arbitrary either: its scope and usability depend on objectively existing matter as well. For in legal studies, too, account has to be taken of the fact that the purpose of a division is to create segments grouping legal institutions that are similar in some respects that are relevant for a jurist. Moreover, the division has to best suit the intended objective. Hence, legal institutions will be classified above all according to their organisation, differences in, and methods of, operation, etc.

Division criteria have to be uniform but only at the same classification tier. For instance, the well-known definition of administration formulated by Otton Mayer: "Verwaltung ist die Tätigkeit des Staates [...] unter seiner Rechtsordnung, außerhalb der Justiz” is actually a form of dual and two-tier classification that could be broken down in the following manner: governance is divided into enacting a legal order (in the sense of enacting statutes, i.e. legal norms of the highest order) and an activity subject to the former. The division criterion in this case is the relation to statutes: either their enactment or implementation. In turn, the subordinate activity is divided into the judicature (administration of justice, Justiz) and the activity that is not judicature. The latter is called administration. Here, the division criterion is different. It can be for instance some characteristic of organisation and forms or methods of action, or so-called substantive criteria. In this approach, administrative law is the law regulating administration thus conceived.

This classification can be expanded further, on one or several planes, depending on the adopted criteria. Administrative law, in such a broad sense, can be subdivided into financial law and administrative law in the strict sense, and the latter may be divided further still into agricultural, wa- 
ter, mining, industrial, transportation administrative law, etc. Here again different division criteria for division will be used than on the higher tier. In the last-mentioned case, we are dealing with many definitions that have a common genus proximum and together make up a non-exhaustive division. Within the same tier, division criteria must not be mixed.

The criteria that are used in such a classification can thus vary: their choice usually depends on the set objective. They may be formal, concerning the form and character of an activity, or substantive, concerning the substance of regulated relations. What follows is a few examples from very different times.

Roman jurists divided law (for didactic purposes) into public and private primarily in accordance with the purpose of the legal institution: safeguarding a public interest or the interest of an individual.

For Montesquieu, the chief criterion of division was the nature of subjects whose legal relations a given legal institution was to regulate. Montesquieu called the relations between the governing and the governed "political law", whereas he called the relations between the governed among themselves "civil law".

The Vienna School (especially František Weyr, 1908, and later Hans Kelsen and Adolf Merkl) took the stance that the division of law into public and private, according to the criterion of the protection of interests (public or private) and on the criterion of the equality or inequality of subjects, does not satisfy the postulate of the so-called science of economy. This discipline calls for a legal division to join what is legally homogeneous and divide what is legally diverse. Therefore, the Vienna School believed that the issue of dividing law into public and private may concern only specific legislation that adopts such a division by enacting separate regulations for each of these segments of law that are usually left undefined. ${ }^{3}$

2 According to Montesquieu “political” law is: les lois dans le rapport qu'ont ceux qui gouvernent avec ceux qui sont gouvernés, while private: les lois dans le rapport que tous les citoyens ont entre eux. C.L. Montesquieu, Esprit des lois, Londres 1777, L. I. Ch. 3.

3 V.A. Merkl, Allgemeines Verwaltungsrecht, Wien-Berlin 1927, pp. 80-85. 
With the above reservations, the author of definitions and classifications is free to choose his criteria. Their legitimacy is based solely on fitness for their intended use and obviously their logical correctness. From this point of view, the adopted criteria should not be rejected beforehand, although they may and should be critically judged in terms of research or practical utility. It must be remembered in this connection that no definition or division will satisfy all postulates or will remedy all the problems of jurists as no definition may at the same time account for all the elements that may prove useful for various needs.

It seems advisable to test these simple propositions by applying them to several oft-disputed issues from the theory of administrative law.

A. "Positive" or "negative" definition of administration. It must be noted first that so-called negative definitions are not negative in any literal sense. Let us take for instance the classic definition that takes administration to be part of state activity that is not legislation or judicature (or administration of justice). It is necessary, in this case, to specify three concepts, making up this definition: to know if some state activity constitutes administration, we must define first what state activity is in general. Next, we must define what legislation and judicature are. Hence, administration will be such (already defined) state activity that has the characteristics of neither legislation nor judicature. Since the classic definition assumes beforehand the separation of powers, the definition of administration itself — until it is demonstrated that, relying on a uniform foundation, it is possible to divide the three kinds of state activity existing in a given system: legislation, administration of justice and administration — must refer to the rest of state activity besides legislation and the administration of justice, following from a dichotomous classification. Otherwise, the division would be erroneous: it would not be exhaustive. If we introduced a partial positive definition, making use of some specific characteristics and not exhausting the scope of administration as the "rest of state activity", we would have to introduce the rest as the fourth category to stay in agreement with the principles of a logical division. Incidentally, as of now, it appears that there is no definition of administra- 
tion that would be able, using the same criterion of division, to differentiate it from legislation and administration of justice at the same time. It looks as if it were necessary to use here a two-stage classification as per Otto Mayer"s definition mentioned earlier.

Can one rule out beforehand the possibility of a "positive" definition of administration (as well as legislation and judicature), one based on a common criterion and confined to the separation of powers into three branches? Any known "positive" definitions do not fit into such a division and are, as a matter of fact, based on different criteria for each of the three branches. Of course, they may also be usable to an extent, but since they are not a segment of division, their usability will be limited inasmuch as they will not be able to explain relationships between various kinds of state activity. If, for instance, administrative law is defined as law regulating "public service”, this may have some significance for the organisation of such an object of study as the attitude of state organs to the satisfaction of citizens” needs. However, this will not be helpful in determining the scope of what colloquially and in legal provisions is called administration, nor in explaining the relationship of administration thus defined and the law that regulates it to other kinds of state activity.

Furthermore, if it is observed that the state performs more and more tasks and that new fields of legal regulation emerge, it can be said beforehand that a regulating positive definition of administrative law, which would differentiate it from other branches of law, i.e. one that would fall into the division and correspond to new legal institutions at the same time, could quickly lose its usability.

B. Formal or substantive criteria. The attempts to define or distinguish administration and administrative law according to substantive criteria (concerning the subject matter of the relations being regulated) have not produced any usable results, as it seems, especially as far the major kinds of state activity are concerned. Social and economic life is subject for the most part to legal regulation in all its forms. Substantive criteria may, however, come in useful to some extent at the lower tiers 
of classification, in particular for didactic purposes (e.g. division of administrative law into the special branches mentioned earlier: agricultural, mining, water, industrial, construction, transport law, etc.).

In addition, reasonable doubts could arise as to whether it is necessary or even advisable for defining administrative law to define substantively state administration in advance. An answer to this question, however, would call for a special study.

C. Formal criteria: concerning the entities involved or the subject matter regulated. Methodologically, it is of course equally correct if the realm of administrative law is specified by reference to the entities involved or the subject matter regulated. In either case, some portion of the law usually called administrative (or perhaps provisions regarded as belonging to administrative law) will be left out. In the former case, we will leave out law regulating the administrative activity of judicial and legislative organs. It is another question if in this case it should not be assumed that judicial organs are in this respect simply administrative organs and if the administrative organs of the Sejm can be identified with the Sejm itself as a legislative organ; after all they are organisationally subordinate, following the principles proper to administrative organs. If, in turn, subject-matter criteria are used, we will leave out the law regulating the norm-giving activity (in the sense of issuing general provisions of law) of the organs commonly considered administrative (e.g. ministers), and decisions in certain areas (e.g. penal-administrative decisions, decisions on compensation for expropriation, etc.).

In practice, the former omission is less strongly felt. For instance, the administrative activity of organs commonly believed to be legislative and judicial, and recognised as such in the Constitution, is as a rule not discussed in the systems and textbooks of administrative law. However, the omission of penal-administrative decisions and ones concerning compensations, or leaving out the norm-giving activity of organs believed to be administrative, is unthinkable. 
Obviously, for special-purpose research, e.g. studies of an administrative act, or even for defining an administrative organ, subject-matter criteria may also prove useful. However, to present the subject-matter in its entirety, the entity-related criteria are believed to be more useful for the simple reason that constitutions themselves create grids of state organs divided into various types, differing in structure, and thus adapted to perform various tasks. First and foremost, however, with respect to state administration, constitutions, as a rule, lay down only the principles of an administrative organ system, while the nature and forms of activity of individual organs are regulated only in very general and fragmentary terms. ${ }^{4}$ On this foundation, however, various "subjectmatter" definitions can be built as well, but in order to specify the types of state activity, it is best to rely on the grid of state organs provided for in a constitution. There are indisputable benefits: practical, didactic and research ones as well.

The above examples show that attempting to define, for instance, administrative law — even for historical and comparative purposes-we are always limited by the existing legal material. However, within the material there is always the possibility of defining a given legal institution using various criteria, i.e. in various ways. There is no single allexplaining definition that only needs to be found. Hence, if the possi-

4 Admittedly, it could be claimed that the very diversity of tasks that makes constitutions set up various bodies adapted in their structure to the tasks to be performed is conceptually superior. In this context, one could cite the origins of the separation of powers that must have stemmed not only from the opinions of jurists or politicians. The separation must have been a result of not only political tendencies: it must have satisfied some objective needs of performing certain state tasks at a certain stage of state development. If, however, we say that the task of administration of justice is to determine the forms of a certain portion of state activity, somebody could rightly claim that the administration of justice exercised by a single-person administrative body-hierarchically subordinate, that is, not independent-is not proper administration of justice, but rather a sui generis act of state coercion. It could be further claimed that true administration of justice is exclusively exercised by an independent body. Moreover, if penal-administrative decisions and ones concerning compensations, issued by an administrative body, are not popularly believed to be "administration of justice", it is a reflection of this claim. This attests to the weight of the organisational aspect that a theoretician must not ignore. 
bility of providing a definition of administrative law is doubted (there are many authors who do, recently for instance Forsthoff), the question must be asked: what definition? For there may be many definitions, and many may have some value. A definition may be broad and precise enough at the same time to be considered useful under given conditions, for example, because of the practice of state organs or for didactic reasons. Conversely, there is no definition that could resolve all difficulties posed by practice, the demands of research and didactic needs.

What then does the question of defining administrative law look like in the context of our legislation? Of course, here too, various definitions and classifications are possible, depending on the adopted criteria. However, the foundation of any regulating definition will be rather heavily restricted by our positive legislation.

Let us take the possibilities our Constitution offers in this respect. Providing for a specific grid of organs, the Constitution defines their structure and in part their hierarchy. By doing this, it also provides a foundation for an "entity-related" definition of particular realms of state activity. The organisational structure and character of individual state organs, however, are rather noticeably connected with the nature of tasks they are made responsible for; it is also easy to see how important the tasks are for determining the subject matter and kind of their activity.

Let us try to divide the state organs listed in the Constitution according to their relation to citizens, in particular, the competence of particular organs to regulate their rights and duties.

If the organs listed in the Constitution are viewed and classified from this point of view, what will immediately meet the eye is the division into two groups. One comprises the legislative organs that enact general legal norms of the highest order independently of other organs, and authoritatively. This means that they decide in general terms pro futuro the scope and content of the legal acts of all other organs of the state. ${ }^{5}$ The other

5 If the foundation of the construction were expanded to include the People's Council Act, it would be necessary to include the local organs of authority that issue independently—but 
group consists of all the other organs that are bound by legislative acts when issuing legal acts.

Among the latter organs, again two groups can be distinguished. One comprises organs that only declare what the law is and in that activity they are subject only to statutes and decrees (Article 52 and Article 25(1)(4) of the Constitution). The other group is comprised of the organs that whenissuing legal acts (general and individual) are in that activity not only subject to statutes and decrees but also, in some scop and manner, to acts issued by superior organs. ${ }^{6}$

Once legislative organs are thus eliminated, we will be left with—as far as the issuing of legal acts is concerned-two types of constitutional organs: organs that in their decision-making are subject only to statutes and decrees, and organs that in their issuance of legal acts (general or individual) are subject also to the acts of superior organs. ${ }^{7}$

Thus, from the adopted point of view, the organs provided for in the Constitution and issuing "executive" legal acts may be divided into

within competence granted by statutes_-local provisions of law.

6 The separate question of subjection to ordinances is purposefully left out of the discussion. For administrative organs, however, an ordinance has, it is believed, the force of an instruction.

7 This kind of division is known in the literature (Merkl) and, as can be seen, can be inferred from the positive-law material. A certain peculiar difficulty arises in it in respect of the Council of Ministers that issues (executive!) legal acts independently of any administrative bodies, while it is neither a legislative nor judicial body, is it? This is, however, a necessary consequence of the hierarchical organisational system (although in our system, a strict hierarchy can hardly be spoken of). The Council of Ministers, after all, is the highest tier of the system (see A. Merkl, op. cit. pp. 42-43). A definition based on the element of subordination to a superior body must contain a suitable reservation in this respect. With such a reservation, from the point of view of the adopted criterion and with the limitation to the organisational grid of state bodies provided for in the Constitution, the division will be exhaustive. Difficulties will arise only when the grid is expanded to include all legislation: it will be seen then that a statute at times assigns to bodies of a particular type competences characteristic of the remit of bodies of a different type. It could be assumed sometimes in such situations that acting in a different capacity, a given body acts in this remit as an body of a different type. With such an expanded foundation, a need to substantially modify the division would arise if, for instance, administrative procedure or penal-administrative provisions eliminated any influence of superior bodies on decision-making bodies or if the provisions on People's Councils would give them, as organs of authority (session), the right to independently - and not executively ("executive powers", Art. 16 of the Act of 1950) — enact local law. This is, however, a different question. 
judicial organs and others. The latter are called administrative organs in the Constitution. Relying on this division, we can further distinguish by analogy administrative law from "judicial” law (civil and criminal) and administrative-law relations from "judicial-law” relations, i.e. ones of civil and criminal law.

As can be seen, the constitutional "entity-related" division of organs, based on their structure, is related to a certain extent to the nature and content of tasks assigned to them. The obtained division, admittedly, will not correspond from our point of view to the entire grid of organs provided for by the Constitution, as it will be too narrow: first, it will not cover all the organs provided for in the Constitution (public prosecutor's offices!); second, it will not encompass the full range of their activity. Instead, it will allow for making the legal nature of their activity more specific, for instance, to set apart the administrative activity of judicial organs. A definition thus obtained may prove to be useful for the interpretation of the nature of a studied legal act. In this case, the definition of an administrative organ and administrative law-administrative law in the broad sense, because as it can be immediately seen it also includes financial law and other cognate branches-may play a role in clearing away doubts concerning interpretation.

The adoption, in reliance on the grid of organs provided for by the Constitution, of the "entity-related" division into judicial and administrative organs - or along the same lines, the division of law into judicial and administrative in the broad sense - does not mean, naturally, that no other equally reasonable divisions and definitions could be made using different criteria. This is especially true for the traditional division of law into public and private. Its legitimacy, as supposedly following from the very nature of law, has been questioned several times already to be sure in the bourgeois theory of law (e.g. Gumplowicz, Vienna School, and Bordeaux School); using new arguments, the theory of socialist law is departing from it as well. ${ }^{8}$ As a rule, legitimate criticism, however, is

8 The point of departure for the Soviet theory is most of the time a sentence by Lenin from a letter to D. J. Kursky of February 1922: “We do not recognise anything "private”, for 
usually directed from specific positions at certain specific ways of understanding this division. It appears that appropriately understood: either as a conventional didactic division used by Roman jurists or as a relative division, based on formal criteria, e.g. on the difference in the situation of parties to a legal relation regulated by law or the manner it is protected, ${ }^{9}$ the division, within certain bounds, is not only entirely correct, but may be useful as well.

Courtroom practice and attempts to replace the term "public-legal" with "administrative-legal” (in a broad sense) still suggest this. The latter is different from the division into judicial and administrative law above all in that it includes criminal-judicial law as part of public law. Although, one certainly could make do without this division, it is valuable for research and practice. It explains well certain differences in the way the branches of law distinguished in this way work. For instance, the division of law into public and private maintains a certain homogeneity of judicial and administrative criminal law (concerning the legal nature of operation and, to a certain extent, also the social function of decisions), whereas the division into administrative law in the broad sense and judicial law undeniably breaks this relationship, admittedly, in favour again of the homogeneity of judicial law.

us everything in the sphere of economy is public-legal and not private [...], therefore, it is necessary to expand state interventionism in private-law relations, to expand the right of the State to abolish "private” contracts ...” etc. (Cit. per: S. Strogovitch, Teoriya gosudarstva i prava, Moscow 1949, p. 441—based on the 3rd edition of Lenin's works; in the 4th edition, I have not found this letter. The 4th edition carries instead another letter to Kursky of 28 Feb. 1922: "It is necessary to increase still further the intervention of the State in privatelaw relations, in “civil matters"”. Essentially, Lenin”s idea is, in the opinion of Strogovitch, that in the socialist economy there is nothing "private", i.e. inaccessible to regulation by the State. Strogovitch believes that in the system of Soviet law there are no grounds for such a division as there is no private ownership of means of production and, consequently, no private law. In turn, what has been called public law in the bourgeois system has a different content and sense in the Soviet system. A. I. Denisov also comments by, based in part on the statement by Marx and Engels on the "illusory nature" of this opposition. A. I. Denisov, Teoriya gosudarstva i prava, Moscow 1948, pp. 407-413; K. Marx, F. Engels, German Ideology. Writings, IV, pp. 53, 227.

9 A review of older theories: J. Hollinger, Das Kriterium des Gegensatzes zwischen dem öffentlichen Recht und dem Privatrecht, Zürich 1904. 
346 | Marian Zimmermann

\section{Literature}

Denisov A.I., Teoriya gosudarstva i prava, Moscow 1948

Hollinger J., Das Kriterium des Gegensatzes zwischen dem öffentlichen

Recht und dem Privatrecht, Zürich 1904.

Marx K., Engels F., German Ideology. Writings, IV.

Merkl A., Allgemeines Verwaltungsrecht, Wien-Berlin 1927.

Montesquieu C. L., Esprit des lois, Londres 1777.

Strogovitch S., Teoriya gosudarstva i prava, Mocow 1949. 